\title{
Evidence for the Integration of Stress-Related Signals by the Rostral Posterior Hypothalamic Nucleus in the Regulation of Acute and Repeated Stress-Evoked Hypothalamo-Pituitary- Adrenal Response in Rat
}

\author{
Tara J. Nyhuis, Cher V. Masini, Heidi E.W. Day, and $\mathbb{C S}^{\text {Serge Campeau }}$ \\ Department of Psychology and Neuroscience, University of Colorado-Boulder, Boulder, Colorado 80309
}

\begin{abstract}
A likely adaptive process mitigating the effects of chronic stress is the phenomenon of stress habituation, which frequently reduces multiple stress-evoked responses to the same (homotypic) stressor experienced repeatedly. The current studies investigated putative brain circuits that may coordinate the reduction of stress-related responses associated with stress habituation, a process that is inadequately understood. Initially, two rat premotor regions that respectively regulate neuroendocrine (medial parvicellular region of the paraventricular hypothalamic nucleus [PaMP]) and autonomic (rostral medullary raphe pallidus [RPa]) responses were targeted with distinguishable retrograde tracers. Two to 3 weeks later, injected animals underwent loud noise stress, and their brains were processed for fluorescent immunohistochemical detection of the tracers and the immediate early gene Fos. A rostral region of the posterior hypothalamic nucleus ( $\mathrm{rPH}$ ), and to a lesser extent, the median preoptic nucleus, exhibited the highest numbers of retrogradely labeled cells from both the RPa and PaMP that were colocalized with loud noise-induced Fos expression. Injections of an anterograde tracer in the $\mathrm{rPH}$ confirmed these connections and suggested that this region may contribute to the coordination of multiple stress-related responses. This hypothesis was partially tested by posterior hypothalamic injections of small volumes of muscimol, which disrupts normal synaptic functions, before acute and repeated loud noise or restraint exposures. In addition to significantly reduced corticosterone release in response to these two distinct stressors, $\mathrm{rPH}$ muscimol disrupted habituation to each stressor modality, suggesting a novel and important contribution of the rostral posterior hypothalamic nucleus in this category of adaptive processes.
\end{abstract}

Key words: anterograde; loud noise; paraventricular nucleus of the hypothalamus; raphe pallidus; restraint; retrograde

Significance Statement

Habituation to stress is a process that possibly diminishes the detrimental health consequences of chronic stress by reducing the amplitude of many responses when the same challenging conditions are experienced repeatedly. Stress elicits a highly coordinated set of neuroendocrine, autonomic, and behavioral responses that are independently and relatively well defined; however, how the brain achieves coordination of these responses and their habituation-related declines is not well understood. The current studies provide some of the first anatomical and functional results suggesting that a specific region of the hypothalamus, the rostral posterior hypothalamic nucleus, targets multiple premotor regions and contributes to the regulation of acute neuroendocrine responses and their habituation to repeated stress.

\section{Introduction}

Stress triggers a constellation of well-orchestrated and coordinated neuroendocrine, autonomic, and behavioral responses that normally help organisms maintain homeostasis and promote survival (Cannon, 1914; Selye, 1936; Ursin and Olff, 1993). However, the benefits of acute stress responses are often diminished under chronic stress conditions, themselves frequently associated with somatic and psychological disorders (Brown et al., 1987;

\footnotetext{
Received Sept. 11, 2015; revised Nov. 2, 2015; accepted Dec. 2, 2015.

Author contributions: T.J.N., C.V.M., H.E.W.D., and S.C. designed research; T.J.N. and C.V.M. performed research; T.J.N., C.V.M., H.E.W.D., and S.C. analyzed data; T.J.N., C.V.M., H.E.W.D., and S.C. wrote the paper.

This work was supported by National Institute of Mental Health Grant MH077152 to S.C. We thank Kirsten Taufer for technical assistance in performing some of the immunohistochemical procedures reported herein.

The authors declare no competing financial interests.
}

Correspondence should be addressed to Dr. Serge Campeau, Department of Psychology and Neuroscience, University of Colorado-Boulder, Boulder, Colorado 80309. E-mail: Serge.Campeau@colorado.edu.

DOI:10.1523/JNEUROSCI.3413-15.2016

Copyright $\odot 2016$ the authors $\quad 0270-6474 / 16 / 360795-11 \$ 15.00 / 0$ 
Kessler, 1997; Kendler et al., 1999; Chrousos, 2000; Vanitallie, 2002; Shively et al., 2009). A key process mitigating the effects of chronic stress is the phenomenon of stress habituation, which normally weakens or eliminates stress-elicited responses to the same (homotypic) stressor experienced repeatedly (McCarty et al., 1992; Martí and Armario, 1998; Grissom and Bhatnagar, 2008; Campeau et al., 2011). Anxiety and mood disorder patients commonly exhibit disrupted habituation, perhaps contributing to the development and/or maintenance of symptoms associated with these disorders (Malmo et al., 1951; Lader and Wing, 1964; Koepke and Pribram, 1967; Brierley and Jamieson, 1974; Chattopadhyay et al., 1980; Roth et al., 1990; Metzger et al., 1999; Rothbaum et al., 2001; Campbell et al., 2014). This relationship, however, is speculative given our limited understanding of the neural circuitry and cellular mechanisms underlying habituation to stress.

Many studies have provided anatomical and functional details of the neural circuits mediating specific stress-evoked responses, including neuroendocrine responses regulated by the hypothalamo-pituitary-adrenocortical (HPA) axis (Sawchenko, 1991; Sawchenko et al., 2000; Herman et al., 2003), various autonomic reactions controlled by brainstem and hypothalamic premotor regions (Cao and Morrison, 2003; Zaretsky et al., 2003a; Cerri and Morrison, 2006; Pham-Le et al., 2011), and behaviors organized through forebrain, hypothalamic, and brainstem circuits (Liebman et al., 1970; LeDoux et al., 1988; Kim et al., 1993; Campeau and Watson, 1997; Canteras et al., 1997; Carrive et al., 1997). All these responses display habituation upon repeated stress exposures (Armario et al., 1984; De Boer et al., 1988; van Raaij et al., 1997; Campeau et al., 2002), and decline at similar rates across different responses (Masini et al., 2008). How the brain achieves these independent response reductions has not been explored extensively.

To address the putative basis of stress habituation, anatomical tracings from two distinct premotor regions were combined with stress-evoked expression of the immediate-early gene Fos (Cullinan et al., 1993; Campeau and Watson, 2000; Sawchenko et al., 2000; Radley et al., 2009). Tracer deposits targeted the rostral region of the raphe pallidus $(\mathrm{RPa})$, which regulates heart rate and core body temperature (Cao and Morrison, 2003; Zaretsky et al., 2003a, b; Cerri and Morrison, 2006; Pham-Le et al., 2011), and the medial parvicellular nucleus of the paraventricular hypothalamus (PaMP), which regulates HPA axis activity (Palkovits, 1977; Makara et al., 1981; Antoni, 1986). Although retrograde tracing from both the RPa (Hosoya et al., 1987; Hermann et al., 1997; Sarkar et al., 2007) and PaMP (Sawchenko, 1991; Sawchenko et al., 2000; Herman et al., 2003) was previously reported, the extent to which $\mathrm{RPa}$ and PaMP afferent inputs overlap and display stress-evoked activity was unknown. Loud noise (audiogenic stress) was used in these initial studies because it elicits multiple stress-related responses (Henkin and Knigge, 1963; Borrell et al., 1980; Segal et al., 1989; Overton et al., 1991; Campeau and Watson, 1997), which readily habituate upon repeated exposures (Armario et al., 1984; De Boer et al., 1988; Bao et al., 1999; Campeau et al., 2002; Masini et al., 2008). This anatomical survey revealed a rostral portion of the posterior hypothalamic nucleus $(\mathrm{rPH})$ as a major origin of stress-active projections to both the PaMP and RPa. This region was therefore functionally inactivated using the $\mathrm{GABA}_{\mathrm{A}}$ receptor agonist muscimol (Martin and Ghez, 1999) to test the necessity of the $\mathrm{rPH}$ in acute audiogenic stress-induced HPA axis responses and their habituation to repeated audiogenic stress exposure. The use of restraint stress verified the generality of the functional findings obtained with
Table 1. Summary of anatomical tracing cases

\begin{tabular}{llllll}
\hline $\begin{array}{l}\text { Target } \\
\text { conditions }\end{array}$ & $\begin{array}{l}\text { Total } \\
N\end{array}$ & $\begin{array}{l}\text { Good PaMP } \\
\text { injections } \\
\text { only }(n)\end{array}$ & $\begin{array}{l}\text { Good RPa } \\
\text { injections } \\
\text { only }(n)\end{array}$ & $\begin{array}{l}\text { Good PaMP and } \\
\text { RPa injections } \\
(n)\end{array}$ & $\begin{array}{l}\text { Good rPH } \\
\text { injections } \\
(n)\end{array}$ \\
\hline $\begin{array}{r}\text { CTb in PaMP; } \\
\text { FG in RPa }\end{array}$ & 40 & 1 & 2 & 3 & - \\
$\begin{array}{c}\text { FG in PaMP; } \\
\text { CTb in RPa }\end{array}$ & 38 & 3 & 1 & 4 & - \\
BDA in rPH & 17 & - & - & - & 3 \\
\hline
\end{tabular}

audiogenic stress, suggesting an important contribution of the rostral posterior hypothalamic nucleus in HPA axis habituation.

\section{Materials and Methods}

Animals

Adult (2- to 3-month-old) male Sprague Dawley rats (Harlan), weighing $300 \pm 5 \mathrm{~g}$ at the time of surgery, were used. Animals were maintained on a $12 \mathrm{~h}: 12 \mathrm{~h}$ light/dark cycle (lights on: 06:00 A.M.) and acclimated to the colony for $\sim 1$ week before surgery. All procedures were approved by the University of Colorado, Boulder Institutional Animal Care and Use Committee, and conformed to the United States of America National Institute of Health Guide for the Care and Use of Laboratory Animals.

\section{Anatomical tracers studies}

Surgeries. General surgical procedures were performed as described previously (Campeau and Watson, 2000; Day et al., 2009). Rats were placed in a Kopf stereotaxic instrument fitted with blunt earbars, with the incisor bar set to $-3.3 \mathrm{~mm}$ (as previously described in Zaretsky et al., 2003a). For tracer injections, glass capillaries of $10-25 \mu \mathrm{m}$ external tip diameter were backfilled with either a $1 \%$ solution of cholera toxin subunit B (CTb; \#104, List Biological Laboratories), dissolved in 0.05 m sodium phosphate buffer, a 2\% solution of FluoroGold (FG; Fluorochrome), dissolved in $0.9 \%$ saline, or a $5 \%$ solution of biotinylated dextran amine (BDA), 10,000 MW (\#D1956, Invitrogen), dissolved in $0.1 \mathrm{~m}$ sodium phosphate buffer. Discrete CTb and FG tracer deposits were made by iontophoresis ( $7 \mathrm{~s}$ on/off for $3-12 \mathrm{~min} ; 1-5 \mu \mathrm{A}$ ) in the PaMP region (0.7 $\mathrm{mm}$ posterior from bregma, $0.1 \mathrm{~mm}$ lateral from the center of the longitudinal sinus, and $7.2 \mathrm{~mm}$ ventral from the dura) or the $\mathrm{RPa}$ region $(2.0$ $\mathrm{mm}$ posterior from the interaural line, centered at the interaural line, and $8.8 \mathrm{~mm}$ ventral from the dura) as described in Table 1 . In additional animals, a deposit of the anterograde tracer BDA was made in the $\mathrm{rPH}$ (2.1 $\mathrm{mm}$ posterior from bregma, $0.2 \mathrm{~mm}$ lateral from the center of the longitudinal sinus, and $7.4 \mathrm{~mm}$ ventral from the dura) to verify the results obtained with the retrograde tracers CTb and FG. Animals were allowed to recover for 2-3 weeks before euthanasia.

The afternoon before euthanasia, rats were transferred from the colony to a behavioral testing room. They were placed, within their home cages, in a ventilated and acoustically insulated chamber, as described previously (Day et al., 2005). The following morning, between 8:00 and 10:00 A.M., rats were exposed to $30 \mathrm{~min} 105 \mathrm{~dB}$ (A scale, dBA) white noise. Rats remained in the chamber for a further 60 min under background noise conditions ( $\sim 60 \mathrm{dBA})$. Rats were then anesthetized (sodium pentobarbital, $0.7 \mathrm{mg}$, i.p.) and perfused transcardially with $150 \mathrm{ml}$ ice-cold PBS solution containing $100 \mathrm{U} / \mathrm{ml}$ heparin, followed by $500 \mathrm{ml}$ of ice-cold 4\% PFA in $0.1 \mathrm{~m}$ sodium phosphate or $0.1 \mathrm{~m}$ borate buffer, $\mathrm{pH}$ 7.4. Brains were removed and postfixed in the same fixative solution overnight at $4^{\circ} \mathrm{C}$ and transferred to $0.1 \mathrm{M}$ sodium phosphate or borate buffer, $\mathrm{pH} 7.4$, containing $30 \%$ sucrose, at $4^{\circ} \mathrm{C}$. After $\sim 48 \mathrm{~h}$, brains were rapidly frozen and sectioned on a Leica cryostat (model 1850; Leica Microsystems). Six series of $35 \mu \mathrm{m}$ sections were collected from the rostral to caudal extent of the brain and stored in cryoprotectant $30 \%$ ethylene glycol, $30 \%$ sucrose in $0.05 \mathrm{M}$ sodium phosphate buffer, $\mathrm{pH} 7.2$ ) at $-20^{\circ} \mathrm{C}$ until immunohistochemical processing.

Immunohistochemistry. Injection sites and retrograde/anterograde labeling were assessed by fluorescence immunohistochemistry for the appropriate tracers, and in combination with the detection of the immediate-early gene Fos that was induced by loud noise before eutha- 
nasia. For cases with appropriate injection sites (Table 1), dual fluorescent immunohistochemical procedures were performed for either Fos and one of the injected tracers, or both retrograde tracers FG and CTb, in one of six section series, respectively. Primary antisera against CTb (goat polyclonal; \#703, List Biological Laboratories, 1:16,000 dilution), FG (rabbit polyclonal; Fluorochrome; 1:50,000 dilution), BDA (CY3conjugated monoclonal mouse anti-biotin; \#200-162-211, Jackson ImmunoResearch Laboratories, 1:1000 dilution), and Fos (rabbit or goat polyclonals; sc-52 or sc-52-G, respectively, Santa Cruz Biotechnology; 1:8000 dilution) were used as appropriate. Antibodies were diluted in a buffer solution of $1 \times$ PBS, containing $0.5 \%$ Triton X-100 (SigmaAldrich), 1\% BSA (Sigma-Aldrich), and 5\% normal donkey serum (Jackson ImmunoResearch Laboratories). Incubations and washes were performed with gentle agitation at room temperature unless otherwise stated. Sections were first rinsed in PBS and then incubated in the immunohistochemical buffer for $1 \mathrm{~h}$, before being transferred to a fresh buffer solution containing the appropriate primary antibody, and incubated at $4^{\circ} \mathrm{C}$ for $\sim 72 \mathrm{~h}$. Sections were then rinsed again in PBS, followed by incubation with appropriate donkey anti-rabbit or anti-goat secondary antibodies conjugated to DyLight or AlexaFluor-488 or -594 (1:200; Jackson ImmunoResearch Laboratories) for $2 \mathrm{~h}$ (DyLight and AlexaFluor dyes have equivalent excitation and emission spectra). After final rinses in PBS, sections were mounted on superfrost plus glass slides (Thermo Fisher Scientific) and covered with VectaShield HardSet (\#H1500; Vector Laboratories) mounting medium and glass covers (Thermo Fisher Scientific). Before covering, some sections were stained with the fluorescent Nissl stain NeuroTrace 500/525 (N21480, Invitrogen; 1:250 dilutions) according to the manufacturer's specifications.

Imaging and quantification. Sections processed for the detection of FG, $\mathrm{CTb}, \mathrm{BDA}$, and Fos were visualized using a Zeiss Axio Imager Z1 upright fluorescent microscope equipped with a monochrome camera (AxioCam MRm), ApoTome attachment (Zeiss Microscopy), at 20X (Plan-Apochromat, $0.8 \mathrm{NA}$ ) or $40 \times$ (EC Plan Neofluar, $0.75 \mathrm{NA}$ ). Profile counts were performed on images digitally acquired with the ApoTome's optical sectioning processing mode (strong filter, average count of 5) in Axiovision software (version 4.8.2) for improved focal contrast and confocal-like quality. Regional boundaries for each ROI were defined from DAPI (mounting medium \#H-1500 with DAPI, Vector Laboratories) or fluorescent Nissl-counterstained sections processed for immunohistochemistry (see above) with the help of a rat brain atlas (Paxinos and Watson, 2004). Profile counts in individual ROI were performed unilaterally (with the exception of the median preoptic area, which is a midline structure) on two different brain sections, corrected using the Abercrombie method (Abercrombie, 1946), multiplied by 6 to estimate the total number of labeled neurons in defined ROI, and averaged for each case. Average percentage colocalization with Fos in ROI was determined by dividing the number of retrogradely labeled profiles also displaying Fos (double-labeled cells) by the total number of retrogradely labeled profiles in a given ROI. Digitally acquired photomicrographs (see Figs. 1-7) were transferred to Photoshop (version 5.5), where contrast/ brightness were adjusted to provide the best visual results. The nomenclature used is that of Paxinos and Watson (2004).

\section{Functional inactivation studies}

Surgeries. Rats were prepared for surgical procedures as described above. An incision was made over the skull, the skin retracted, and a small box drilled through the skull to allow implantation of bilateral chronic guide cannulae (26 gauge cut $9 \mathrm{~mm}$ below pedestal; Plastics One) above the rostral posterior hypothalamus $(2.9 \mathrm{~mm}$ posterior from bregma, $6.7 \mathrm{~mm}$ ventral from the dura, with each cannula placed on the lateral edge of the longitudinal sinus), which was determined empirically in pilot animals. The cannulae were held in place using dental cement anchored on 3 jeweler's screws fixed to the animal's skull. Stylets, which were flush with the tip of the guide cannulae, were inserted to keep the cannulae free of organic substances, and externally closed with dust caps. Rats were given buprenorphine (analgesic) and Baytril (antibiotic) postoperatively and monitored daily during recovery from surgery for at least $7 \mathrm{~d}$ before additional experimental manipulations.
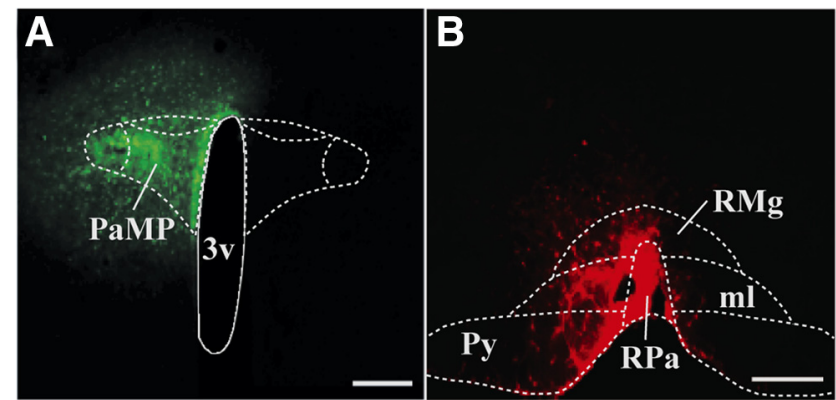

Figure 1. A, Photomicrograph of a rat brain coronal section representing a retrograde tracer injection site in medial parvicellular region of the paraventricular hypothalamic nucleus (PaMP; green; (ase 6), at $1.7 \mathrm{~mm}$ posterior to bregma. $\boldsymbol{B}$, Similar depiction of retrograde tracer injection in the rostral region of the nucleus raphe pallidus ( $\mathrm{RPa}$; red; Case 47), at $11.0 \mathrm{~mm}$ posterior to bregma. 3v, Third ventricle; RMg, nucleus raphe magnus; Py, pyramidal tracts; ml, medial lemniscus. Scale bars, $200 \mu \mathrm{m}$.

Repeated audiogenic stress. Fifty-five animals were used in the audiogenic stress study, in four independent replications. After surgical recovery, rats were transported to the behavioral suites, handled, and habituated to the injection procedures. The rats in their home cages were placed in quiet acoustic chambers for 45 min for 4 consecutive days. Twenty-four to 48 hours following the fourth preexposure, rats were exposed to the first of three consecutive daily $30 \mathrm{~min}$ loud noise (95-98 dBA) sessions, $24 \mathrm{~h}$ apart. On these days, rats were brought from the colony to the laboratory for at least $30 \mathrm{~min}$ before injections. Animals were gently handled by an experimenter while the dust caps/stylets were removed. Bilateral injectors (33 gauge, Plastics One), connected via PE tubing to $10 \mu \mathrm{l}$ syringes fixed to a precision pump (\#53220, Stoelting), were then inserted into the guide cannulae. Muscimol (Sigma; $200 \mathrm{nl} /$ side, $0.5 \mathrm{mg} / \mathrm{ml}$ ) in aCSF ( NaCl, $140 \mathrm{~mm} ; \mathrm{KCl}, 3.35 \mathrm{~mm} ; \mathrm{MgCl}_{2}, 1.15 \mathrm{~mm}$; $\mathrm{CaCl}_{2}, 1.26 \mathrm{~mm} ; \mathrm{Na}_{2} \mathrm{HPO}_{4}, 1.2 \mathrm{~mm} ; \mathrm{NaH}_{2} \mathrm{PO}_{4}, 0.3 \mathrm{~mm}$, adjusted to $\mathrm{pH}$ : 7.4) or aCSF alone (vehicle) were injected at a constant rate of $200 \mathrm{nl} /$ min. Muscimol was chosen because it offers a relatively specific synaptic inactivation mechanism through the ubiquitously located $\mathrm{GABA}_{\mathrm{A}}$ receptors, leading to rapid, long-lasting, and reversible cellular hyperpolarization (Martin and Ghez, 1999). Injectors were left in place for an additional $1 \mathrm{~min}$ after the injection to allow for drug diffusion. Injectors were then removed, stylets and dust caps replaced, and the rats returned to their home cages and placed immediately in the acoustic chambers. Loud noise (95-98 dBA) was turned on 15 min following the end of the injection, for $30 \mathrm{~min}$. Immediately upon noise termination, following the first noise exposure, rats were removed from the acoustic chambers and a tail blood sample was collected for corticosterone hormone assessment (see below). Similar procedures were followed 24 and $48 \mathrm{~h}$ later for the second and third loud noise or control exposure, but without blood sampling. Forty-eight hours after the third noise exposure, rats were brought back to the behavioral suite, placed in the acoustic chambers without any drug injections (i.e., drug-free), and exposed to a $30 \mathrm{~min}$ loud noise; and again, immediately upon noise termination, tail blood samples were collected.

Repeated restraint stress. Fifty-eight animals were used in the restraint stress study, in three independent replications. At least 7 days following recovery from the cannulae implantation, the restraint stress study was initiated and performed as described above for audiogenic stress, with the exception that animals were exposed to $30 \mathrm{~min}$ of restraint stress, within their home cages, and in the acoustic chambers defined above. Restrainers were constructed from $0.64 \mathrm{~cm}$ wire mesh, exactly as described previously (Masini et al., 2012b). Additional no stress and acute stress groups were also added to this study. Corticosterone assays were performed as described previously (Day et al., 2009) on all the samples from the repeated loud noise and restraint studies, respectively, to reduce interassay variability, and performed according to the manufacturer's instructions (kit\#901-097, Assay Designs), with the exception that the10 $\mu \mathrm{l}$ samples of plasma were diluted 1:50 in sample buffer and placed in a 


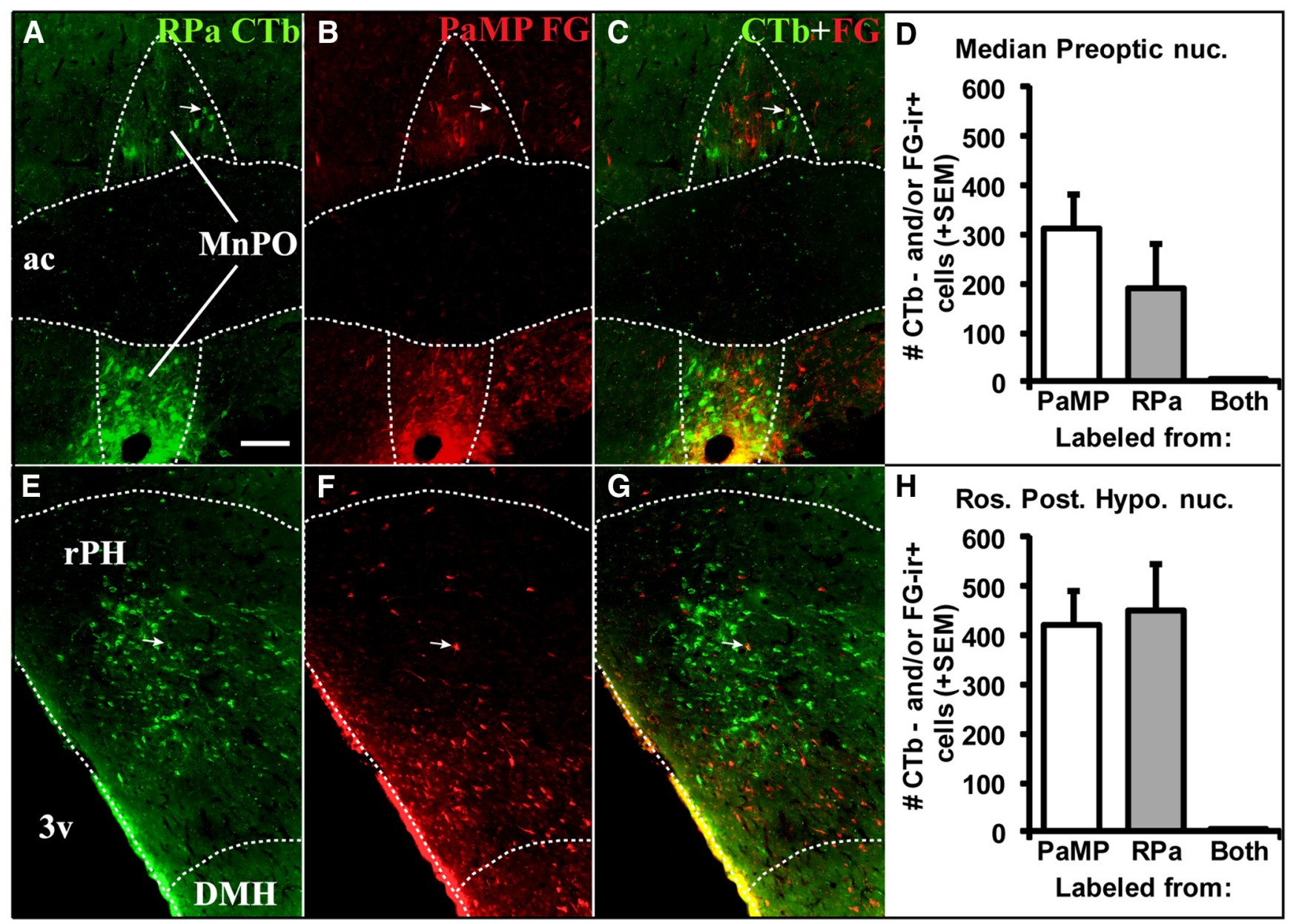

Figure 2. Retrograde tracer labeling in $\mathrm{MnPO}(0.1 \mathrm{~mm}$ posterior to bregma; $\boldsymbol{A}-\boldsymbol{C})$ and $\mathrm{PPH}(3.3 \mathrm{~mm}$ posterior to bregma; $\boldsymbol{E}-\boldsymbol{G})$ following tracer injections in $\mathrm{RPa}(\boldsymbol{A}, \boldsymbol{E}$, green-labeled cells) and $\operatorname{PaMP}(\boldsymbol{B}, \boldsymbol{F}$; red-labeled cells) in Case 62. Superimposed photomicrographs of retrograde labeling from the two target regions $(\boldsymbol{C}, \boldsymbol{G})$ indicate very few cells displaying colocalization of the two distinct tracers in the same cells (white arrows). Counts of retrogradely labeled cells (+1SEM) immunoreactive for CTb and/or FG in the MnPO (D) and rPH $(\boldsymbol{H})$ indicated relatively similar cell numbers originating from the RPa and PaMP tracer injections, but very few cells colocalized the two tracers (Both). 3v, Third ventricle; ac, anterior commissure; DMH, dorsomedial hypothalamic nucleus. Scale bar (in $\boldsymbol{A}): A-H, 100 \mu \mathrm{m}$.

$65^{\circ} \mathrm{C}$ water bath for $1 \mathrm{~h}$ to heat inactivate corticosterone binding proteins (within-assay variability between duplicates $<8 \%$ ).

Data analyses. Individual CORT values were transformed to their natural logarithmic values due to unequal variances obtained for this measure in both the loud noise and restraint studies. Plasma CORT values on day 1 and the drug-free test day were statistically evaluated with a repeated-measures ANOVA, with day (day 1 or drug-free test day) as a repeated measure to determine extent of habituation, and drug treatment (vehicle or muscimol) and exposure conditions (control or stress exposure) as between-subjects variables when appropriate. Repeatedmeasures ANOVAs on CORT from the vehicle group only with stress exposure day (day 1 and drug-free test day) as the within-subject factor were used to determine habituation in these groups. Additional one-way ANOVAs between groups to further assess the effects of drug and stress were performed to test for differences between groups on individual days. The level of statistical significance was set at $p<0.05$.

Anatomical verifications. Twenty-four to $48 \mathrm{~h}$ after the final experimental manipulations, animals were injected with $200 \mathrm{nl} /$ side of either $0.1 \%$ methylene blue or $0.5 \mathrm{mg} / \mathrm{ml}$ BODIPY TMR-X muscimol conjugate (Invitrogen) to assess guide cannulae placement and injectate spread. Immediately (for the dye injected animals) or $45 \mathrm{~min}$ (for the BODIPY- muscimol-injected animals) following this injection, animals were decapitated and the brains removed and frozen. Brains were then sectioned $(35 \mu \mathrm{m})$ on a cryostat (Leica 1850), for cannulae placements verification under bright-field (dye-injected) or epifluorescence (BODIPY, muscimol-injected) microscopy (Zeiss Axio Imager Z1).

\section{Results}

Anatomical tracers studies

Seven cases displayed well-placed tracer injections in both the PaMP and RPa targets, whereas 4 additional cases had good injection placements only in the PaMP and 3 more cases had good injection placements only in the $\mathrm{RPa}$ (Table 1). PaMP tracer deposits were centered between 1.8 and $1.9 \mathrm{~mm}$ posterior to bregma, whereas those in the RPa were located from 11.6 to 11.9 $\mathrm{mm}$ posterior to bregma, with variable spread from the main injection sites in both regions. Representative photographs of PaMP and RPa injection sites are shown in Figure 1. Individual patterns of retrograde labeling obtained from both regions were consistent with those reported previously for the PaMP (Sawchenko and Swanson, 1983; Sawchenko, 1991; Cullinan et al., 1996; Sawchenko et al., 1996; 2000; Herman and Cullinan, 1997; Campeau and Watson, 2000; Herman et al., 2003; Radley and Sawchenko, 2011) and RPa (Hosoya et al., 1987; Hermann et al., 1997; Cao et al., 2004; Samuels et al., 2004; Sarkar et al., 2007), and will therefore not be described in detail. Instead, focus was given to regions that consistently provided innervation to both target areas. The pattern of RPa retrograde labeling was more restricted than that from the PaMP, especially in the forebrain, with a handful of regions displaying retrograde labeling from 

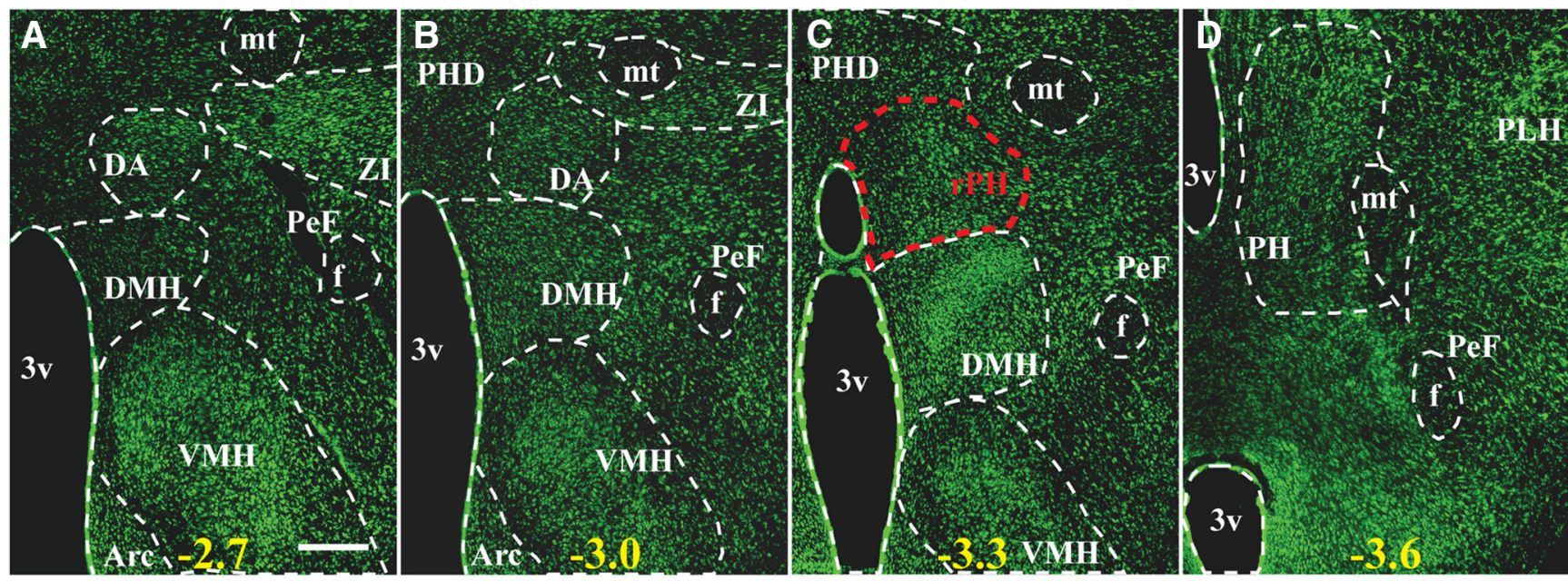

Figure 3. Fluorescent Nissl-stained (green; NeuroTrace 500/525) rat brain sections at four posterior hypothalamic levels characterizing nuclear boundaries based on Paxinos and Watson's rat brain atlas. The region displaying high retrogradely labeled cell numbers from RPa and PaMP retrograde tracer injections is indicated in red and corresponds to a rostral region of the posterior hypothalamic nucleus ( $\mathrm{rPH}$; $\boldsymbol{C}$. Numbers at the bottom of each micrograph indicate the approximate distance from bregma ( $\mathrm{mm}$ ) from anterior to posterior levels $(\boldsymbol{A}-\boldsymbol{D})$. $3 \mathrm{v}$, Third ventricle; Arc, arcuate nucleus; DA, dorsal hypothalamic area; DMH, dorsomedial hypothalamic nucleus; $\mathrm{f}$, fornix; $\mathrm{mt}$, mammillothalamic tract; PeF, perifornical nucleus; $\mathrm{PH}$, posterior hypothalamic nucleus; PHD, posterior hypothalamic area, dorsal part; PLH, peduncular part of the lateral hypothalamus; VMH, ventromedial hypothalamic nucleus; ZI, zona incerta. Scale bar: (in $\boldsymbol{A}$ ) $\boldsymbol{A}-\boldsymbol{D}$, $300 \mu \mathrm{m}$.

both target structures. The regions consistently demonstrating the highest numbers of retrogradely labeled cells from both the $\mathrm{PaMP}$ and $\mathrm{RPa}$ tracer injections were the median preoptic nucleus (MnPO) and a restricted region of the posterior hypothalamic nucleus, as shown in Figure 2. A specific rostral and dorsal region within the posterior hypothalamus $(\mathrm{rPH}, 3.3-3.5 \mathrm{~mm}$ posterior to bregma), as illustrated and defined in Figure 3 (region delimited in red outline) through a series of green fluorescent Nissl-stained sections, consistently displayed high numbers of retrogradely labeled cells from both the PaMP and RPa. This region maps very closely with a region intimately associated with cardiovascular regulation (Samuels et al., 2004). Importantly, even if the $\mathrm{MnPO}$ and $\mathrm{rPH}$ regions provided consistent mutual innervation to $\mathrm{PaMP}$ and $\mathrm{RPa}$, the origin of the cell populations contributing to the projections from these respective regions was virtually independent, as very few retrogradely double-labeled cells were observed in any of the 7 cases sustaining accurate double injections (Fig. 2D,H). Additional regions providing mutual, but unequal and more limited retrograde projections to PaMP and RPa included the medial preoptic area and nucleus, the dorsomedial hypothalamic nuclei, the periaqueductal gray regions (most numerous in the ventrolateral subdivision), and the nucleus of the solitary tract (data not shown).

Tracer deposits that variably missed the target regions provided information about the specificity of innervation to the PaMP and RPa regions. For instance, RPa injections centered 12 $\mathrm{mm}$ or further caudal to bregma gave rise to many fewer retrogradely labeled cells in $\mathrm{rPH}$ and $\mathrm{MnPO}$, consistent with a prior report (Hermann et al., 1997). Tracer injections in the dorsally located raphe magnus also produced few labeled cells in $\mathrm{rPH}$. And whereas anteriorly located injection sites from PaMP deposits generated high numbers of retrogradely labeled cells in the preoptic nuclei, these injections provided few cells in the $\mathrm{rPH}$ region. Likewise, injections centered in the ventrally located medial aspect of the lateral hypothalamus or dorsally located zona incerta, compared with PaMP, provided few retrogradely labeled cells in the $\mathrm{rPH}$ region (data not shown).

To verify the retrograde results described above, anterograde tracer (BDA) deposits targeting $\mathrm{rPH}$ were performed. Although retrograde labeling is sometimes observed with the 10,000 MW BDA, very little retrograde labeling was observed in all cases examined; therefore, retrograde results will not be discussed in these cases. Three BDA injections were determined to be discrete and centered in $\mathrm{rPH}$ (3.3-3.5 mm posterior to bregma, near the dorsal edge of the third ventricle), as indicated in Figure 4, with variable tracer spread. Representative images of PaMP and $\mathrm{RPa}$ display consistent, mostly ipsilateral (in PaMP), projections (Fig. $4 B-D)$ from $\mathrm{rPH}$ BDA deposits. Many additional regions were significantly targeted by fibers and terminal-like boutons from $\mathrm{rPH}$, including, among the densest projections, the cingulate and prelimbic cortices, lateral septum, anterior ventral aspects of the bed nucleus of the stria terminalis, paraventricular thalamic nucleus, and the central gray region (data not shown). As Figure 4 further indicates, multiple loud noise-induced Fos-like immunoreactive neurons were observed in close apposition to $\mathrm{rPH}$ axon terminal-like processes in the RPa (Fig. 4B) and PaMP (Fig. $4 C, D)$ regions.

\section{Retrograde labeling (FG or CTb) and Fos colocalization}

Increases in neural activity through synaptic signaling have been associated with the induction of c-fos mRNA expression and its protein product, Fos (Morgan and Curran, 1989; Sheng and Greenberg, 1990). These are commonly used indices of increased neural activity following stressor exposure (Sawchenko et al., 1996; Kovács, 1998; Hoffman and Lyo, 2002). Importantly, under the current experimental and immunohistochemical detection conditions, Fos protein expression is virtually undetectable in nonstressed, control rat brains (data not shown). A subset of regions that displayed retrograde tracing from both the PaMP and the RPa showed varying levels of colocalization of retrograde tracers with Fos. The MnPO consistently displayed colocalization in all PaMP and $\mathrm{RPa}$ cases examined. Based on 4 retrograde tracing cases from the RPa with effective loud noise-induced Fosimmunoreactive labeling, $14.7 \%$ of the total retrogradely labeled MnPO cells coexpressed Fos, as shown in Figure 5. A similar assessment on 7 retrograde tracing cases from the PaMP indicated that $10.7 \%$ of $\mathrm{MnPO}$ cells immunoreactive for a retrograde tracer also expressed loud noise-induced Fos immunoreactivity 
(Fig. 5). These results corroborate those of Campeau and Watson (2000), also indicating moderate levels of PaMP retrograde tracer colocalization with Fos following audiogenic stress in the median preoptic nucleus. Based on the same cases described above for the median preoptic nucleus analysis, $35 \%$ and $33.6 \%$ of retrogradely labeled cells from the RPa and PaMP, respectively, demonstrated coexpression with loud noise-induced Fos immunoreactivity in rPH (Fig. 6). No other brain regions examined displayed such consistent patterns of retrograde labeling from both the PaMP and RPa, combined with loud noise-induced Fos-like immunoreactivity. Given the relatively unique and high percentages of stress-induced Fos coexpression in PaMP- and $\mathrm{RPa}-$ projecting cell populations of the $\mathrm{rPH}$, this region was then evaluated for its contribution to regulation of the HPA axis in response to acute and habituating regimens of repeated loud noise and restraint stress, respectively. This initial choice was further dictated by prior reports indicating stress modulation by various manipulations at levels corresponding to $\mathrm{rPH}$ (see Discussion), but not to MnPO (Yoshida et al., 2009).

\section{Functional inactivation of the $\mathrm{rPH}$}

Twenty-eight rats tested in the audiogenic stress study were determined to have bilateral cannulae placements centered between 3.3 and $3.5 \mathrm{~mm}$ posterior to bregma ( $n=13$ Veh, $n=15$ Musc), which was proximal to the region identified to innervate both the PaMP and $\mathrm{RPa}$ in the initial anatomical studies, as shown in Figure 7. However, two animals from the Veh group and one animal from the Musc group were excluded from further analysis because their plasma CORT on day 1 or test day was $>3$ SDs from their respective group means. Additional Musc-injected rats $(n=6)$ had cannulae placements centered from 2.0 to $2.5 \mathrm{~mm}$ posterior to bregma with no spread to the $\mathrm{rPH}$, and their results are described independently. Other animals were not included in the study due to severe anorexia or infection that necessitated euthanasia or placements that missed the ROI $(n=21)$. Of the 58 animals used in the restraint stress study, 40 were determined to have bilateral cannulae placements centered between 3.3 and $3.5 \mathrm{~mm}$ posterior to bregma ( $n=10 \mathrm{Veh}, n=12$ Musc in repeated restraint conditions; $n=5$ Veh, $n=6$ Musc in acute restraint conditions on test day; and $n=4$ Veh, $n=3$ Musc in the never restrained conditions). Animals $(n=18)$ were excluded from the restraint study due to problems similar to those described above in the audiogenic stress study.

\section{Audiogenic stress}

A repeated-measures ANOVA for plasma CORT values with noise exposure day (day 1 or test) as the within-subjects factor and treatment group (Veh or Musc) as the between-subjects factor revealed an overall day $\times$ group interaction effect $\left(F_{(1,23)}=\right.$ 15.17, $p=0.001)$. One-way ANOVAs on day 1 and test days revealed between-group differences in plasma CORT on day 1 $\left(F_{(1,23)}=5.90, p=0.023\right)$ as well as the test day $\left(F_{(1,23)}=5.73, p=\right.$ $0.025)$. An additional repeated-measures ANOVA on animals in the Veh group only, with noise exposure day (day 1 and test) as a within-subjects factor revealed differences between days $\left(F_{(1,10)}\right.$ $=9.03, p=0.013$ ), indicating that the CORT response significantly habituated in the Veh group, as shown in Figure 8.

A repeated-measures ANOVA using plasma CORT values obtained from animals with cannulae placements centered between 2.0 and $2.5 \mathrm{~mm}$ posterior to bregma revealed no day by group effect $\left(F_{(1,5)}=0.745, p=0.428\right)$, as shown in Figure 8 (gray bars). A one-way ANOVA revealed no differences between plasma CORT values obtained from animals in the Veh group and animals with missed placements anterior to the $\mathrm{rPH}$ (anterior muscimol) on the test day $\left(F_{(1,15)}=0.43, p=0.52\right)$, suggesting similar habituated responses.

\section{Restraint stress}

A repeated-measures ANOVA using CORT values of only the repeatedly restrained animals with restraint exposure day (day 1 and test) as the within-subjects factor and injection Group (Veh or Musc) as the between-subjects factor revealed an overall day $\times$ group interaction effect $\left(F_{(1,20)}=45.509, p<\right.$ 0.001 ), as shown in Figure 9. A within-subjects analysis over days in the repeatedly restrained Veh-treated group indicated significant habituation of the CORT response on the test day $\left(F_{(1,9)}=9.93, p=0.012\right)$. 


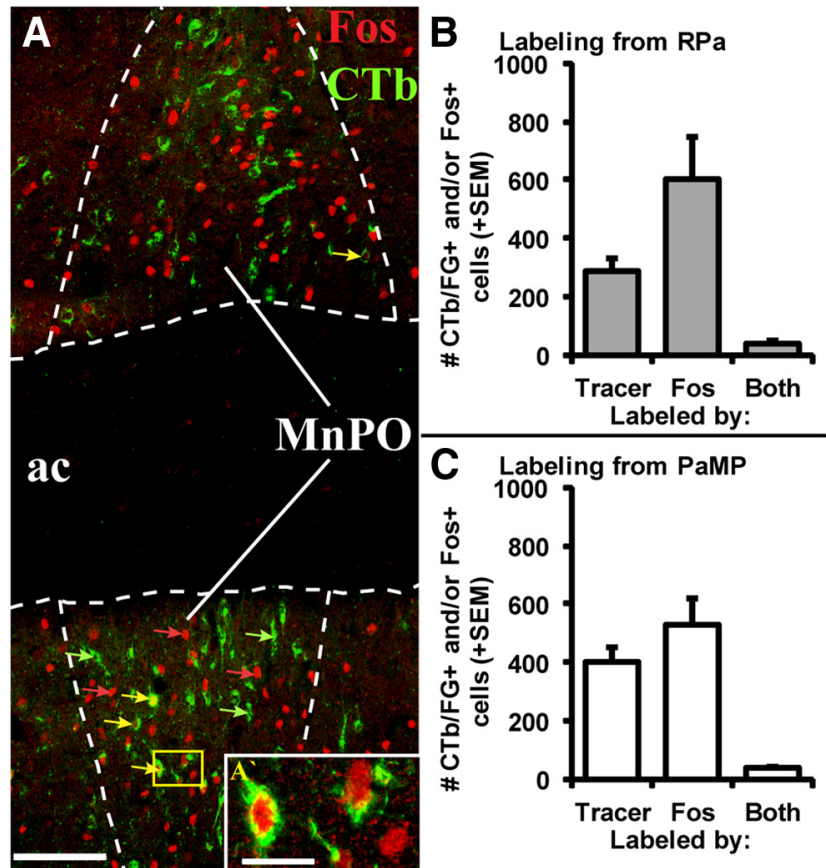

Figure 5. A, Representative double fluorescence immunohistochemical labeling of retrograde tracer (CTb deposited in PaMP, green; Case 53) and audiogenic stress-induced Fos immunoreactivity (red) in MnPO ( $0.1 \mathrm{~mm}$ posterior to bregma). Scale bar, $100 \mu \mathrm{m}$. Examples of single retrogradely labeled cells (green arrows), single Fos-labeled cells (red arrows), and cells expressing both markers (yellow arrows) are indicated, with the inset ( $\boldsymbol{A}^{\prime}$; yellow box in $\boldsymbol{A}$ ) providing magnified (40X objective) representation of single- and double-labeled processes. Scale bar, $20 \mu \mathrm{m}$. Mean + SEM cell counts of retrogradely labeled (Tracer), Fos-labeled (Fos), and double-labeled cells (Both) in MnPO following tracer injections in the $\mathrm{RPa}(\boldsymbol{B})$ or $\mathrm{PaMP}(\boldsymbol{C})$. Approximately $13 \%$ of all retrogradely labeled cells from either the RPa or PaMP were also immunoreactive for Fos. $n=4-7$ cases per condition. ac, Anterior commissure.

Independent additional analyses on day 1 and the test days were performed to investigate the effects of the various control manipulations. A one-way ANOVA on CORT values from day 1 with exposure groups (no restraint, acute restraint on test day, or repeated restraint) and injection treatment (Veh or Musc) as between-subjects variables indicated significant stress effect $\left(F_{(2,34)}=12.42, p<0.001\right)$, and a stress $\times$ injection interaction $\left(F_{(1,34)}=4.01, p=0.027\right)$. A Tukey post hoc analysis revealed that overall, the two control unrestrained groups were similar to each other, but respectively different from the restrained group on day $1(p=0.02)$. A $t$ test was conducted on the means of the restrained rats given either Musc or Veh on day 1, which indicated a significant attenuation of CORT in the muscimol-injected rats $\left(t_{(21)}=28.75, p<0.001\right)$, as indicated in Figure 9. A one-way ANOVA on CORT values from the test day (drug free) with stress groups (never restrained, acutely restrained on test day, or repeatedly restrained) and prior injection treatments (Veh or Musc) as between-subjects variables indicated significant effects of stress $\left(F_{(2,34)}=61.35, p<0.001\right)$, prior injection $\left(F_{(1,34)}=\right.$ $6.46, p=0.016$ ), but no interaction effect. Tukey post hoc analysis indicated that overall, the restrained groups were similar to each other $(p>0.05)$, but respectively different from the unrestrained control groups $(p<0.001)$. A $t$ test was conducted on the means of the repeatedly restrained rats given prior Veh or Musc, which indicated a significantly greater plasma CORT value in the rats previously injected with muscimol $\left(t_{(21)}=14.57, p=0.001\right)$, as shown in Figure 9. The CORT values of the acutely restrained rats on the test day were not significantly different between the previously Veh- and Musc-injected rats $\left(t_{(10)}=3.25, p=0.11\right.$; Fig.
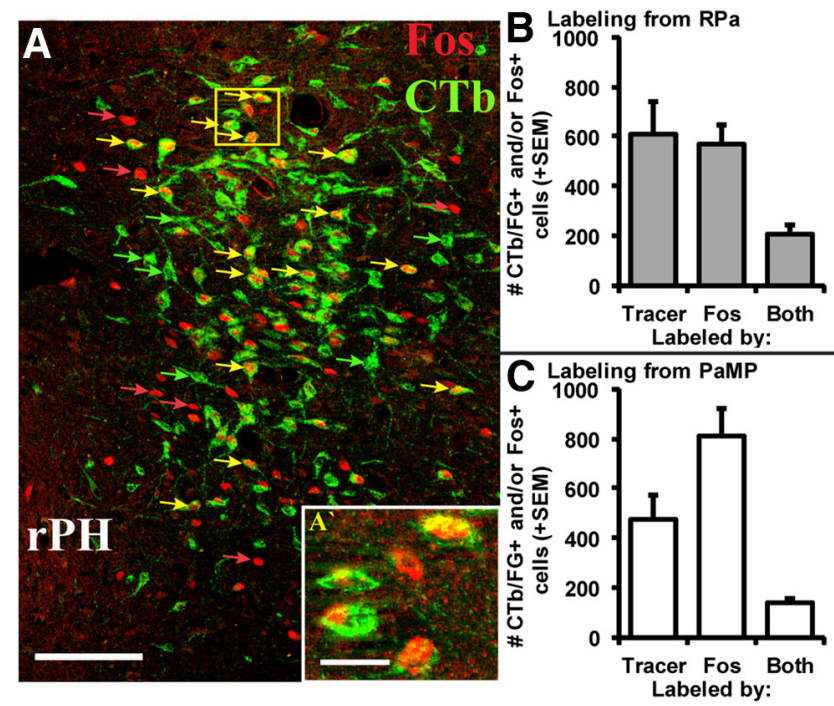

Figure 6. A, Representative double fluorescence immunohistochemical labeling of retrograde tracer (CTb deposited in RPa, green; Case 60) and audiogenic stress-induced Fos immunoreactivity (red) in rPH (3.3 mm posterior to bregma). Scale bar, $100 \mu \mathrm{m}$. Examples of single retrogradely labeled cells (green arrows), single Fos-labeled cells (red arrows), and cells ex pressing both markers (yellow arrows) are indicated, with the inset $\left(\boldsymbol{A}^{\prime}\right.$; yellow box in $\boldsymbol{A}$ ) providing magnified ( $40 \times$ objective) representation of single- and double-labeled processes. Scale bar, $20 \mu \mathrm{m}$. Counts + SEM of retrogradely labeled (Tracer), Fos-labeled (Fos), and double-labeled cells (Both) in rPH following tracer injections in the RPa (B) or PaMP (C). Ap proximately $34 \%$ of all retrogradely labeled cells from either the RPa or PaMP were also immunoreactive for Fos. $n=6$ or 7 cases per condition.

9), suggesting that prior $\mathrm{rPH}$ muscimol treatments did not induce nonspecific drug effects on subsequent stress-induced corticosterone responses.

\section{Discussion}

Evidence was obtained suggesting that cells of the $\mathrm{rPH}$ innervate at least two premotor brain regions that regulate a number of neuroendocrine $(\mathrm{PaMP})$ and autonomic $(\mathrm{RPa})$ responses evoked by stress exposure. While both regions provided some of the largest numbers of retrogradely labeled cells in $\mathrm{rPH},<1 \%$ of these cells demonstrated colocalization of the retrograde tracers. This novel finding strongly suggests that distinct cell populations emanating from the $\mathrm{MnPO}$ and $\mathrm{rPH}$ uniquely target individual premotor regions responsible for the well-orchestrated responses typically evoked by stress. Furthermore, when combined with Fos expression as an index of audiogenic stress-induced activity, the $\mathrm{rPH}$ accounted for more than twice the percentage of retrogradely labeled cells colocalized with Fos ( $34 \%)$, compared with similar measurements in the MnPO $(\sim 13 \%)$. These results suggest that the rPH may uniquely contribute to the coordination of multiple stress-elicited responses. This hypothesis was partly supported by the finding that disrupted $\mathrm{rPH}$ synaptic activity significantly reduced acute audiogenic and restraint stressinduced HPA axis responses, similar to the results of prior studies focusing mostly on autonomic indices (for review, see Fontes et al., 2011). Importantly, this regulation was found to extend to habituation of repeated homotypic stress situations, in which the HPA axis response reduction normally observed to repeated stress was significantly impaired by muscimol-induced disruption of normal $\mathrm{rPH}$ synaptic activity. Overall, these results suggest that the $\mathrm{rPH}$ participates in the coordination of multiple responses triggered by stress and provide some of the initial func- 

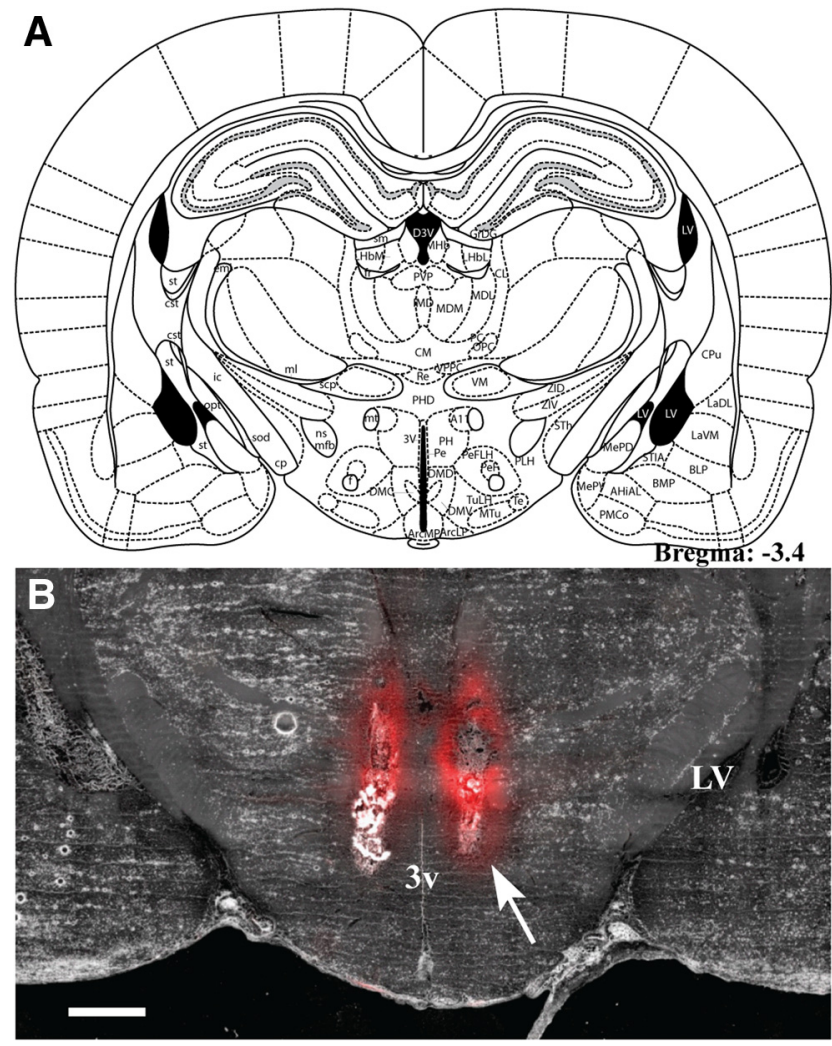

Figure 7. A, Plate from Paxinos and Watson's rat brain atlas (Paxinos and Watson, 2004; their Fig. 62) representing the location of injector cannulae tips for ACSF (Veh) or muscimol injections in the repeated loud noise and restraint stress studies. $\boldsymbol{B}$, Coronal section of a freshfrozen brain slice $(35 \mu \mathrm{m})$ following bilateral injections of $200 \mathrm{nl}$ of a BODIPY TMR-X muscimol conjugate (red) targeting the rostral posterior hypothalamic nucleus ( $3.4 \mathrm{~mm}$ posterior to bregma). Note the restricted lateral dispersion of muscimol from the injector tips (white arrow), which appears more extensive in the ventrodorsal plane. $3 \mathrm{v}$, Third ventricle; LV, lateral ventricle. Scale bar, $1000 \mu \mathrm{m}$.

tional evidence suggesting that the $\mathrm{rPH}$ significantly contributes to stress adaptation in the form of habituation to stress.

The dual retrograde results obtained from the PaMP and $\mathrm{RPa}$ were consistent with reports on projections to these regions obtained in independent studies (see Introduction). Interestingly, only a few regions were consistently observed to exhibit relatively large cell numbers from both injection targets simultaneously, even if additional regions contained large numbers of cells uniquely labeled from a single injection target (e.g., anteroventral bed nucleus of the stria terminalis from PaMP injections). These reproducible and consistent anatomical results provided important support for the specificity and accuracy of the dual injections and strengthened the novel findings that independent cell populations from the $\mathrm{MnPO}$ and $\mathrm{rPH}$ are relatively uniquely positioned to influence multiple distinct premotor regions. This is reminiscent of independent cell populations of other forebrain regions (e.g., bed nuclei of the stria terminalis) contributing distinct innervation of different target regions (Kim et al., 2013; Sparta et al., 2013). These findings were confirmed by anterograde labeling from $\mathrm{rPH}$, identifying significant fibers and terminal-like processes in the PaMP and RPa. Additional afferent projections were noted in regions, such as the prefrontal cortex, lateral septum, bed nuclei of the stria terminalis, other preoptic and hypothalamic nuclei, and the periaqueductal gray, which also expressed stress-induced Fos immunoreactivity. $\mathrm{rPH}$ projections to the periaqueductal gray (ter Horst and Luiten, 1986; Vertes

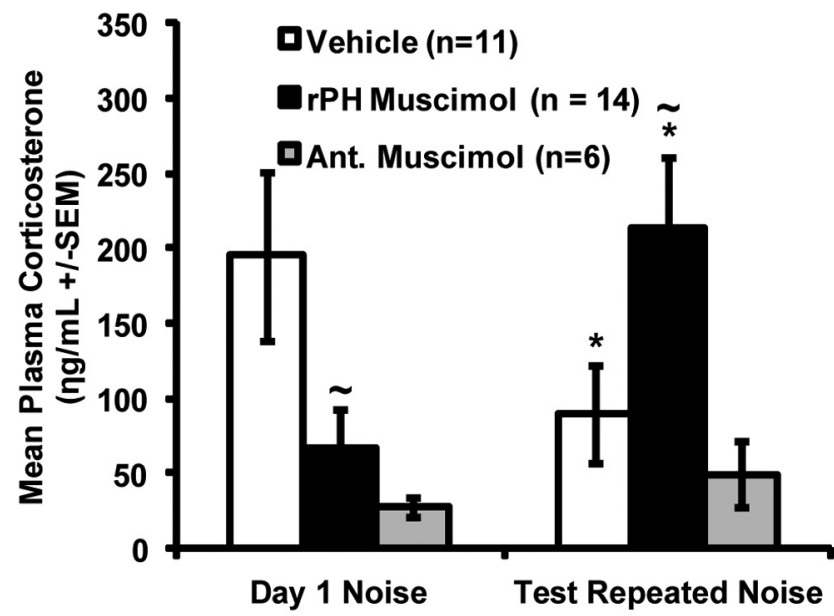

Figure 8. Mean \pm SEM plasma corticosterone ( $\mathrm{ng} / \mathrm{ml}$ ) obtained in vehicle-injected (aCSF, white bars) and muscimol-injected rats (black and gray bars) after a 30 min exposure to the first (day 1) of 3 loud noise repeated exposure ( $24 \mathrm{~h}$ apart), and after the injection-free fourth loud noise exposure (test) conducted $48 \mathrm{~h}$ after the third loud noise experience. Black bars represent the results of rats with verified bilateral cannulae placements in $\mathrm{rPH}(3.3-3.5 \mathrm{~mm}$ posterior to bregma, $n=14)$. Gray bars represent the results of rats with cannulae in more anterior locations (2.0-2.5 mm posterior to bregma, $n=6)$. *Significant within-group differences from day $1(p<0.05)$. Significantly different from the Vehicle group on day 1 and test, respectively $(p<0.05)$.

and Crane, 1996) may be of importance due to their associations with defensive behavioral reactions that are frequently reported during stressor exposures (Liebman et al., 1970; LeDoux et al., 1988; Kim et al., 1993; Campeau and Watson, 1997; Carrive et al., 1997; Grissom et al., 2008). Together, these observations suggest that the rostral posterior hypothalamic nucleus is anatomically positioned to orchestrate multiple responses consistently evoked by diverse stress situations.

The $\mathrm{rPH}$ accounted for more than twice the percentage of retrogradely labeled cells colocalized with Fos, compared with similar counts in the $\mathrm{MnPO}$, regardless of tracer combination among the two targets, arguing against tracer specific biases. A purportedly identical region centered $3.3 \mathrm{~mm}$ posterior to bregma at the dorsolateral edge of the third ventricle was reported to express the highest levels of retrogradely labeled cells from $\mathrm{RPa}$ injections with restraint-induced Fos compared with any preoptic regions (Sarkar et al., 2007), and were similar to the results of additional retrograde labeling studies from the $\mathrm{RPa}$, in rats (Cao et al., 2004; Samuels et al., 2004). These findings provide accruing evidence that the rPH, as defined in Paxinos and Watson's and Swanson's nomenclature (Swanson, 1998; Paxinos and Watson, 2004), may importantly contribute to the regulation of multiple responses elicited by stress. This is also a region from which sympathetic, neuroendocrine, and behavioral responses are most robustly and consistently elicited from minute injections of excitatory amino acid receptor agonists or $\mathrm{GABA}_{\mathrm{A}}$ receptor antagonists (Waldrop et al., 1988; Bailey and Dimicco, 2001; Cao et al., 2004; Samuels et al., 2004; Fontes et al., 2011). In contrast, the $\mathrm{MnPO}$ has not been reported to regulate psychological stressrelated responses, even if its role in thermoregulatory functions is well established (Yoshida et al., 2009). Given these considerations, injections of the $\mathrm{GABA}_{\mathrm{A}}$ receptor agonist muscimol were initially directed at the $\mathrm{rH}$, which further confirmed its significant contribution to acute stress-evoked HPA axis activation. A similar assessment should eventually be performed in MnPO. Injection of the fluorescently labeled BODIPY TMR-X muscimol 


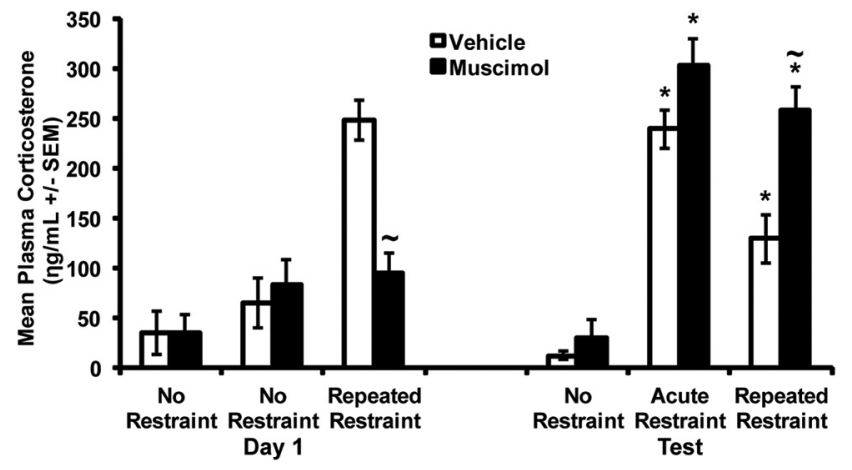

Figure 9. Mean \pm SEM plasma corticosterone $(\mathrm{ng} / \mathrm{ml})$ obtained in vehicle-injected (aCSF, white bars) and muscimol-injected rats (black bars) after a 30 min exposure to the first (day 1) of 3 restraint (or no restraint) repeated exposures ( $24 \mathrm{~h}$ apart), and after the injection-free fourth restraint (or no restraint) exposure (test) conducted $48 \mathrm{~h}$ after the third restraint/no restraint episodes. All rats included in this histogram had verified rPH bilateral cannulae placements (3.3-3.5 mm posterior to bregma) and are represented in the same groups on day 1 and test. Leftmost bars of each day represent the values of injected rats never restrained to determine possible nonspecific effects of repeated muscimol injections on test day corticosterone release (Veh, $n=4$; Musc, $n=3$ ). Middle bars of each day tested the possibility that repeated muscimol injections significantly increased or decreased acute stress-induced corticosterone release on the test day (Veh, $n=5$; Musc, $n=6$ ). Rightmost bars of each day evaluated the effects of $\mathrm{rPH}$ muscimol injections on both acute and repeated restraint corticosterone release (Veh, $n=10$; Musc, $n=12$ ), similar to that tested for loud noise. *Significant withingroup differences from day $1(p<0.05)$. $\sim$ Significantly different from the Vehicle group on day 1 and test, respectively $(p<0.05)$.

indicated that the diffusion of the $\mathrm{GABA}_{\mathrm{A}}$ receptor agonist in a volume of $200 \mathrm{nl}$ was generally limited to a radius of $0.4 \mathrm{~mm}$ from the injector tip, with slightly more extended diffusion up the cannulea tracts. In rats with verified cannulae placements in $\mathrm{rPH}$, muscimol reliably attenuated the acute plasma CORT response to both loud noise and restraint stress compared with vehicleinjected animals. These results are in agreement with similar functional studies investigating stress-induced autonomic responses (Stotz-Potter et al., 1996a, b; McDougall et al., 2004; Fontes et al., 2011), providing additional support for the overall hypothesis that the $\mathrm{rPH}$ is an integral component of a circuit coordinating and regulating multiple responses to various stress situations.

The current studies further suggested that the rPH is a necessary component of a circuit underlying habituation to stress; disruption of normal synaptic activity by muscimol in this region during repeated stress exposures significantly hindered habituation of plasma CORT to loud noise or restraint stress as observed on the drug-free test day. The restraint stress study included a number of additional control conditions (no stress as well as acute restraint controls), which indicated no adverse effects of acute or repeated vehicle or muscimol posterior hypothalamic injections on basal or later acute stress-evoked corticosterone levels. In addition, the outcome of the repeated muscimol/restraint group on the drug-free test day is most similar to an acute response to restraint, arguing against nonspecific effects of muscimol injections. In the audiogenic stress study, several animals were determined to have placements outside of rPH. A number of these placements were rostral to the $\mathrm{rPH}$, and more intimately centered in the dorsomedial nucleus of the hypothalamus $(\mathrm{DMH})$. In the current study, muscimol injection in the rostrally located DMH attenuated the acute HPA response to stress; but in contrast to animals with placements in the $\mathrm{rPH}$, these animals displayed habituated HPA responses to the repeated loud noise exposures similar to the vehicle-treated rats, even if their acute
HPA responses were reliably attenuated by the muscimol injections. Additional studies will be required to distinguish the role and manner in which the closely located dorsomedial hypothalamic nucleus regulates stress-evoked HPA responses given its different connectional profile. The above result further suggests that the disruption of habituated HPA responses by $\mathrm{rPH}$ synaptic interference is not simply produced through disruption of acute responses. Together, the results suggest that the $\mathrm{rPH}$ is important not only for regulating acute responses to different stressors, but it is also necessary for the acquisition of habituated HPA responses to different repeated homotypic stress situations. Concurrent interference with both acute and habituated HPA responses makes it difficult to precisely identify the locus of habituation-related plasticity, given that $\mathrm{rPH}$ not only receives innervation from multiple sensory and limbic structures, but in turn projects to many limbic and effector regions. Disrupted $\mathrm{rPH}$ activity could therefore interfere with habituation-related modifications locally or in regions receiving stress-related signals from $\mathrm{rPH}$. Further dissection and manipulations of rPH circuitry, including intracellular signaling components, will be necessary to identify more precisely the locus and mechanisms underlying habituation to repeated stress.

The current study provides evidence that the $\mathrm{rHH}$ powerfully influences endocrine responses to both audiogenic and restraint stress and, as such, may function as an important integrator of multiple sensory signals generated from different sensory modalities (Campeau et al., 1997; Day et al., 2009). The posterior hypothalamus receives highly processed information from the frontal, parietal, and insular cortices, subcortical limbic regions including different amygdaloid nuclei, septum, bed nuclei of the stria terminalis and hippocampus, and multiple diencephalic and brainstem structures (Cavdar et al., 2001), which likely all contribute to regulate its activity. Overall, this places the rostral posterior hypothalamus in a central position to integrate multiple sources of sensory, homeostatic, and limbic information, and use this information to coordinate and modify multiple responses triggered by stress. Based on these initial findings, it will be important to further assess the role of the $\mathrm{rPH}$ on stress habituation of multiple responses assessed simultaneously (Grissom et al., 2008; Masini et al., 2012a) to test fully the generality of the proposed stress integrative function of this region.

\section{References}

Abercrombie M (1946) Estimation of nuclear population from microtome sections. Anat Rec 94:239-247. CrossRef Medline

Antoni FA (1986) Hypothalamic control of adrenocorticotropin secretion: advances since the discovery of 41-residue corticotropin-releasing factor. Endocrine Rev 7:351-378. CrossRef Medline

Armario A, Castellanos JM, Balasch J (1984) Adaptation of anterior pituitary hormones to chronic noise stress in male rats. Behav Neural Biol 41:71-76. CrossRef Medline

Bailey TW, Dimicco JA (2001) Chemical stimulation of the dorsomedial hypothalamus elevates plasma ACTH in conscious rats. Am J Physiol Regul Integr Comp Physiol 280:R8-R15. Medline

Bao G, Metreveli N, Fletcher EC (1999) Acute and chronic blood pressure response to recurrent acoustic arousal in rats. Am J Hypertens 12: 504-510. CrossRef Medline

Borrell J, Torrellas A, Guaza C, Borrell S (1980) Sound stimulation and its effects on the pituitary-adrenocortical function and brain catecholamines in rats. Neuroendocrinology 31:53-59. CrossRef Medline

Brierley H, Jamieson R (1974) Anomalous stress reactions in patients suffering from depression and anxiety. J Neurol Neurosurg Psychiatry 37: 455-462. CrossRef Medline

Brown GW, Bifulco A, Harris TO (1987) Life events, vulnerability and onset of depression: some refinements. Br J Psychiatry 150:30-42. CrossRef Medline 
Campbell ML, Gorka SM, McGowan SK, Nelson BD, Sarapas C, Katz AC, Robison-Andrew EJ, Shankman SA (2014) Does anxiety sensitivity correlate with startle habituation? An examination in two independent samples. Cogn Emot 28:46-58. CrossRef Medline

Campeau S, Watson SJ (1997) Neuroendocrine and behavioral responses and brain pattern of c-fos induction associated with audiogenic stress. J Neuroendocrinol 9:577-588. Medline

Campeau S, Watson SJ Jr (2000) Connections of some auditory-responsive posterior thalamic nuclei putatively involved in activation of the hypothalamo-pituitary-adrenocortical axis in response to audiogenic stress in rats: an anterograde and retrograde tract tracing study combined with Fos expression. J Comp Neurol 423:474-491. CrossRef Medline

Campeau S, Akil H, Watson SJ (1997) Lesions of the medial geniculate nuclei specifically block corticosterone release and induction of c-fos mRNA in the forebrain associated with loud noise stress in rats. J Neurosci 17: 5979-5992. Medline

Campeau S, Dolan D, Akil H, Watson SJ Jr (2002) c-fos mRNA induction in acute and chronic audiogenic stress: possible role of the orbitofrontal cortex in habituation. Stress 5:121-130. CrossRef Medline

Campeau S, Liberzon I, Morilak D, Ressler K (2011) Stress modulation of cognitive and affective processes. Stress 14:503-519. CrossRef Medline

Cannon WB (1914) The emergency function of the adrenal medulla in pain and the major emotions. Am J Physiol 33:356-372.

Canteras NS, Chiavegatto S, Ribeiro do Valle LE, Swanson LW (1997) Severe reduction of rat defensive behavior to a predator by discrete hypothalamic chemical lesions. Brain Res Bull 44:297-305. CrossRef Medline

Cao WH, Morrison SF (2003) Disinhibition of rostral raphe pallidus neurons increases cardiac sympathetic nerve activity and heart rate. Brain Res 980:1-10. CrossRef Medline

Cao WH, Fan W, Morrison SF (2004) Medullary pathways mediating specific sympathetic responses to activation of dorsomedial hypothalamus. Neuroscience 126:229-240. CrossRef Medline

Carrive P, Leung P, Harris J, Paxinos G (1997) Conditioned fear to context is associated with increased Fos expression in the caudal ventrolateral region of the midbrain periaqueductal gray. Neuroscience 78:165-177. CrossRef Medline

Cavdar S, Onat F, Aker R, Sehirli U, San T, Yananli HR (2001) The afferent connections of the posterior hypothalamic nucleus in the rat using horseradish peroxidase. J Anat 198:463-472. CrossRef Medline

Cerri M, Morrison SF (2006) Corticotropin releasing factor increases in brown adipose tissue thermogenesis and heart rate through dorsomedial hypothalamus and medullary raphe pallidus. Neuroscience 140:711-721. CrossRef Medline

Chattopadhyay P, Cooke E, Toone B, Lader M (1980) Habituation of physiological responses in anxiety. Biol Psychiatry 15:711-721. Medline

Chrousos GP (2000) The role of stress and the hypothalamic-pituitaryadrenal axis in the pathogenesis of the metabolic syndrome: neuroendocrine and target tissue-related causes. Int J Obes Relat Metab Disord 24:S50-S55. CrossRef Medline

Cullinan WE, Herman JP, Watson SJ (1993) Ventral subicular interaction with the hypothalamic paraventricular nucleus: evidence for a relay in the bed nucleus of the stria terminalis. J Comp Neurol 332:1-20. CrossRef Medline

Cullinan WE, Helmreich DL, Watson SJ (1996) Fos expression in forebrain afferents to the hypothalamic paraventricular nucleus following swim stress. J Comp Neurol 368:88-99. CrossRef Medline

Day HE, Nebel S, Sasse S, Campeau S (2005) Inhibition of the central extended amygdala by loud noise and restraint stress. Eur J Neurosci 21: 441-454. CrossRef Medline

Day HE, Masini CV, Campeau S (2009) Reversible inactivation of the auditory thalamus disrupts HPA axis habituation to repeated loud noise stress exposures. Brain Res 1276:123-130. CrossRef Medline

De Boer SF, Slangen JL, van der Gugten J (1988) Adaptation of plasma catecholamine and corticosterone responses to short-term repeated noise stress in rats. Physiol Behav 44:273-280. CrossRef Medline

Fontes MA, Xavier CH, de Menezes RC, Dimicco JA (2011) The dorsomedial hypothalamus and the central pathways involved in the cardiovascular response to emotional stress. Neuroscience 184:64-74. CrossRef Medline

Grissom N, Bhatnagar S (2008) Habituation to repeated stress: get used to it. Neurobiol Learn Mem 92:215-224. CrossRef Medline

Grissom N, Kerr W, Bhatnagar S (2008) Struggling behavior during re- straint is regulated by stress experience. Behav Brain Res 191:219-226. CrossRef Medline

Henkin RI, Knigge KM (1963) Effect of sound on the hypothalamicpituitary-adrenal axis. Am J Physiol 204:910-914. Medline

Herman JP, Cullinan WE (1997) Neurocircuitry of stress: central control of the hypothalamo-pituitary-adrenocortical axis. Trends Neurosci 20: 78-84. CrossRef Medline

Herman JP, Figueiredo H, Mueller NK, Ulrich-Lai Y, Ostrander MM, Choi DC, Cullinan WE (2003) Central mechanisms of stress integration: hierarchical circuitry controlling hypothalamo-pituitary-adrenocortical responsiveness. Front Neuroendocrinol 24:151-180. CrossRef Medline

Hermann DM, Luppi PH, Peyron C, Hinckel P, Jouvet M (1997) Afferent projections to the rat nuclei raphe magnus, raphe pallidus and reticularis gigantocellularis pars alpha demonstrated by iontophoretic application of choleratoxin (subunit b). J Chem Neuroanat 13:1-21. CrossRef Medline

Hoffman GE, Lyo D (2002) Anatomical markers of activity in neuroendocrine systems: are we all 'Fos-ed out?' J Neuroendocrinol 14:259-268. CrossRef

Hosoya Y, Ito R, Kohno K (1987) The topographical organization of neurons in the dorsal hypothalamic area that project to the spinal cord or to the nucleus raphe pallidus in the rat. Exp Brain Res 66:500-506. CrossRef Medline

Kendler KS, Karkowski LM, Prescott CA (1999) Causal relationship between stressful life events and the onset of major depression. Am J Psychiatry 156:837-841. CrossRef Medline

Kessler RC (1997) The effects of stressful life events on depression. Annu Rev Psychol 48:191-214. CrossRef Medline

Kim JJ, Rison RA, Fanselow MS (1993) Effects of amygdala, hippocampus, and periaqueductal gray lesions on short- and long-term contextual fear. Behav Neurosci 107:1093-1098. CrossRef Medline

Kim SY, Adhikari A, Lee SY, Marshel JH, Kim CK, Mallory CS, Lo M, Pak S, Mattis J, Lim BK, Malenka RC, Warden MR, Neve R, Tye KM, Deisseroth K (2013) Diverging neural pathways assemble a behavioural state from separable features in anxiety. Nature 496:219-223. CrossRef Medline

Koepke JE, Pribram KH (1967) Habituation of the vasoconstriction response as a function of stimulus duration and anxiety. J Comp Physiol Psychol 64:502-504. CrossRef Medline

Kovács KJ (1998) c-Fos as a transcription factor: a stressful (re)view from a functional map. Neurochem Int 33:287-297. CrossRef Medline

Lader MH, Wing L (1964) Habituation of the psycho-galvanic reflex in patients with anxiety states and in normal subjects. J Neurol Neurosurg Psychiatry 27:210-218. CrossRef Medline

LeDoux JE, Iwata J, Cicchetti P, Reis DJ (1988) Different projections of the central amygdaloid nucleus mediate autonomic and behavioral correlates of conditioned fear. J Neurosci 8:2517-2529. Medline

Liebman JM, Mayer DJ, Liebeskind JC (1970) Mesencephalic central gray lesions and fear-motivated behavior in rats. Brain Res 23:353-370. CrossRef Medline

Makara GB, Stark E, Kárteszi M, Palkovits M, Rappay G (1981) Effects of paraventricular lesions on stimulated ACTH release and CRF in stalkmedian eminence of the rat. Am J Physiol 240:E441-E446. Medline

Malmo RB, Shagass C, Heslam RM (1951) Blood pressure response to repeated brief stress in psychoneurosis: a study of adaptation. Can J Psychol 5:167-179. CrossRef Medline

Martí O, Armario A (1998) Anterior pituitary response to stress: timerelated changes and adaptation. Int J Dev Neurosci 16:241-260. CrossRef Medline

Martin JH, Ghez C (1999) Pharmacological inactivation in the analysis of the central control of movement. J Neurosci Methods 86:145-159. CrossRef Medline

Masini CV, Day HE, Campeau S (2008) Long-term habituation to repeated loud noise is impaired by relatively short interstressor intervals in rats. Behav Neurosci 122:210-223. CrossRef Medline

Masini CV, Babb JA, Nyhuis TJ, Day HE, Campeau S (2012a) Auditory cortex lesions do not disrupt habituation of HPA axis responses to repeated noise stress. Brain Res 1443:18-26. CrossRef Medline

Masini CV, Day HE, Gray T, Crema LM, Nyhuis TJ, Babb JA, Campeau S (2012b) Evidence for a lack of phasic inhibitory properties of habituated stressors on HPA axis responses in rats. Physiol Behav 105:568-575. CrossRef Medline

McCarty R, Konarska M, Stewart RE (1992) Adaptation to stress: A learned response? In: Stress: neuroendocrine and molecular approaches (Kvetn- 
ansky R, McCarty R, Axelrod J, eds), pp 521-535. New York: Gordon and Breach Science.

McDougall SJ, Widdop RE, Lawrence AJ (2004) Medial prefrontal cortical integration of psychological stress in rats. Eur J Neurosci 20:2430-2440. CrossRef Medline

Metzger LJ, Orr SP, Berry NJ, Ahern CE, Lasko NB, Pitman RK (1999) Physiologic reactivity to startling tones in women with posttraumatic stress disorder. J Abnorm Psychol 108:347-352. CrossRef Medline

Morgan JI, Curran T (1989) Stimulus-transcription coupling in neurons: role of cellular immediate early genes. Trends Neurosci 12:459-462. CrossRef Medline

Overton JM, Kregel KC, Davis-Gorman G, Seals DR, Tipton CM, Fisher LA (1991) Effects of exercise training on responses to central injection of CRF and noise stress. Physiol Behav 49:93-98. CrossRef Medline

Palkovits M (1977) Neural pathways involved in ACTH regulation. Ann N Y Acad Sci 297:455-476. CrossRef Medline

Paxinos G, Watson C (2004) The rat brain in stereotaxic coordinates, Ed 5. San Diego: Academic.

Pham-Le NM, Cockburn C, Nowell K, Brown J (2011) Activation of GABAA or 5HT1A receptors in the raphé pallidus abolish the cardiovascular responses to exogenous stress in conscious rats. Brain Res Bull 86: 360-366. CrossRef Medline

Radley JJ, Sawchenko PE (2011) A common substrate for prefrontal and hippocampal inhibition of the neuroendocrine stress response. J Neurosci 31:9683-9695. CrossRef Medline

Radley JJ, Gosselink KL, Sawchenko PE (2009) A discrete GABAergic relay mediates medial prefrontal cortical inhibition of the neuroendocrine stress response. J Neurosci 29:7330-7340. CrossRef Medline

Roth WT, Ehlers A, Taylor CB, Margraf J, Agras WS (1990) Skin conductance habituation in panic disorder patients. Biol Psychiatry 27:12311243. CrossRef Medline

Rothbaum BO, Kozak MJ, Foa EB, Whitaker DJ (2001) Posttraumatic stress disorder in rape victims: autonomic habituation to auditory stimuli. J Trauma Stress 14:283-293. CrossRef Medline

Samuels BC, Zaretsky DV, DiMicco JA (2004) Dorsomedial hypothalamic sites where disinhibition evokes tachycardia correlate with location of raphe-projecting neurons. Am J Physiol Regul Integr Comp Physiol 287: R472-R478. CrossRef Medline

Sarkar S, Zaretskaia MV, Zaretsky DV, Moreno M, DiMicco JA (2007) Stress- and lipopolysaccharide-induced c-fos expression and nNOS in hypothalamic neurons projecting to medullary raphe in rats: a triple immunofluorescent labeling study. Eur J Neurosci 26:2228-2238. CrossRef Medline

Sawchenko PE (1991) The final common path: issues concerning the organization of central mechanisms controlling corticotropin secretion. In: Stress neurobiology and neuroendocrinology (Brown M, Koob G, Rivier C, eds), pp 55-71. New York: Marcel Dekker.

Sawchenko PE, Swanson LW (1983) The organization of the forebrain afferents to the paraventricular and supraoptic nuclei. J Comp Neurol 218: 121-144. CrossRef Medline

Sawchenko PE, Brown ER, Chan RKW, Ericsson A, Li HY, Roland BL, Kovács KJ (1996) The paraventricular nucleus of the hypothalamus and the functional neuroanatomy of visceromotor responses to stress. In: Progress in brain research: the emotional motor system (Holstege G, Bandler R, Saper CB, eds), pp 201-222. Amsterdam: Elsevier.
Sawchenko PE, Li HY, Ericsson A (2000) Circuits and mechanisms governing hypothalamic responses to stress: a tale of two paradigms. Prog Brain Res 122:61-78. Medline

Segal DS, Kuczenski R, Swick D (1989) Audiogenic stress response: behavioral characteristics and underlying monoamine mechanisms. J Neural Transm 75:31-50. CrossRef Medline

Selye H (1936) A syndrome produced by diverse nocuous agents. Nature 138:32. CrossRef Medline

Sheng M, Greenberg ME (1990) The regulation and function of c-fos and other immediate early genes in the nervous system. Neuron 4:477-485. CrossRef Medline

Shively CA, Register TC, Clarkson TB (2009) Social stress, visceral obesity, and coronary artery atherosclerosis: product of a primate adaptation. Am J Primatol 71:742-751. CrossRef Medline

Sparta DR, Jennings JH, Ung RL, Stuber GD (2013) Optogenetic strategies to investigate neural circuitry engaged by stress. Behav Brain Res 255: 19-25. CrossRef Medline

Stotz-Potter EH, Morin SM, DiMicco JA (1996a) Effect of microinjection of muscimol into the dorsomedial or paraventricular hypothalamic nucleus on air stress-induced neuroendocrine and cardiovascular changes in rats. Brain Res 742:219-224. CrossRef Medline

Stotz-Potter EH, Willis LR, DiMicco JA (1996b) Muscimol acts in dorsomedial but not paraventricular hypothalamic nucleus to suppress cardiovascular effects of stress. J Neurosci 16:1173-1179. Medline

Swanson LW (1998) Brain maps: structure of the rat brain, Ed 2. Amsterdam: Elsevier.

ter Horst GJ, Luiten PGM (1986) The projections of the dorsomedial hypothalamic nucleus in the rat. Brain Res Bull 16:231-248. CrossRef Medline

Ursin H, Olff M (1993) The stress response. In: Stress: from synapse to syndrome (Stanford SC, Salmon P, eds), pp 3-22. San Diego: Academic.

van Raaij MT, Dobbe CJ, Elvers B, Timmerman A, Schenk E, Oortigiesen M, Wiegant VM (1997) Hormonal status and the neuroendocrine response to a novel heterotypic stressor involving subchronic noise exposure. Neuroendocrinology 65:200-209. CrossRef Medline

Vanitallie TB (2002) Stress: a risk factor for serious illness. Metabolism 51: 40-45. CrossRef Medline

Vertes RP, Crane AM (1996) Descending projections of the posterior nucleus of the hypothalamus: Phaseolus vulgaris leucoagglutinin analysis in the rat. J Comp Neurol 374:607-631. CrossRef Medline

Waldrop TG, Bauer RM, Iwamoto GA (1988) Microinjection of GABA antagonists into the posterior hypothalamus elicits locomotor activity and a cardiorespiratory activation. Brain Res 444:84-94. CrossRef Medline

Yoshida K, Li X, Cano G, Lazarus M, Saper CB (2009) Parallel preoptic pathways for thermoregulation. J Neurosci 29:11954-11964. CrossRef Medline

Zaretsky DV, Zaretskaia MV, DiMicco JA (2003a) Stimulation and blockade of $\operatorname{GABA}(\mathrm{A})$ receptors in the raphe pallidus: effects on body temperature, heart rate, and blood pressure in conscious rats. Am J Physiol Regul Integr Comp Physiol 285:R110-R116. CrossRef Medline

Zaretsky DV, Zaretskaia MV, Samuels BC, Cluxton LK, DiMicco JA (2003b) Microinjection of muscimol into raphe pallidus suppresses tachycardia associated with air stress in conscious rats. J Physiol 546:243-250. CrossRef Medline 